\title{
HOX transcription factors and the prostate tumor microenvironment
}

\author{
Richard Morgan'1, Hardev S. Pandha² \\ ${ }^{I}$ Institute of Cancer Therapeutics, Faculty of Life Sciences, University of Bradford, Bradford BD7 1DP, UK. \\ ${ }^{2}$ Faculty of Health and Medical Sciences, University of Surrey, Guildford, Surrey GU2 7XH, UK.
}

Correspondence to: Prof. Richard Morgan, Institute of Cancer Therapeutics, Faculty of Life Sciences, University of Bradford, Bradford BD7 1DP, UK. E-mail: r.morgan3@bradford.ac.uk

How to cite this article: Morgan R, Pandha HS. HOX transcription factors and the prostate tumor microenvironment. J Cancer Metastasis Treat 2017;3:278-87.

Article history:

Received: 15 May 2017

First Decision: 3 Jul 2017

Revised: 7 Jul 2017

Accepted: 14 Aug 2017

Published: 6 Dec 2017

Key words:

Prostate cancer,

tumor microenvironment,

HOX,

PBX,

metastasis,

angiogenesis

\begin{abstract}
It is now well established that the tumor microenvironment plays an essential role in the survival, growth, invasion, and spread of cancer through the regulation of angiogenesis and localized immune responses. This review examines the role of the HOX genes, which encode a family of homeodomain-containing transcription factors, in the interaction between prostate tumors and their microenvironment. Previous studies have established that $H O X$ genes have an important function in prostate cancer cell survival in vitro and in vivo, but there is also evidence that HOX proteins regulate the expression of genes in the cancer cell that influence the tumor microenvironment, and that cells in the microenvironment likewise express $H O X$ genes that confer a tumor-supportive function. Here we provide an overview of these studies that, taken together, indicate that the $H O X$ genes help mediate cross talk between prostate tumors and their microenvironment.
\end{abstract}

\section{INTRODUCTION}

In addition to cancer cells, tumor tissue contains a variety of host cells, extracellular matrix components, and secreted proteins that together constitute the tumor microenvironment ${ }^{[1]}$. Crosstalk between the tumor and its microenvironment has an important role in tumor development, including the recruitment of immune cells and vascular cells, both of which can have profound effects on the survival and spread of the tumor and are therefore targets for cancer therapy ${ }^{[2-4]}$. In this review, we consider the role of the
HOX family of transcription factors in the interaction between prostate tumors and their microenvironment.

\section{THE HOX GENES}

Early embryonic development is characterized by a number of overlapping signaling events that give rise to stable transcriptional states and these in turn confer specific identities at both the cellular and tissue level. Many of the transcription factors that are responsible for regulating embryonic development were originally characterized by the distinct phenotypes caused by

This is an open access article licensed under the terms of Creative Commons Attribution 4.0 International License (https://creativecommons.org/licenses/by/4.0/), which permits unrestricted use, distribution, and reproduction in any medium, as long as the original author is credited and the new creations are licensed under the identical terms.

For reprints contact: service@oaepublish.com
}

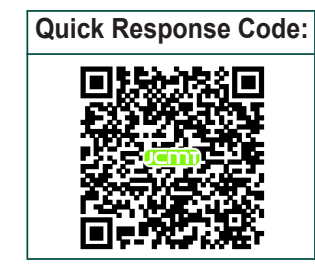


mutations in either their reading frame or regulatory regions, and one of the most notable examples of this are the HOX genes ${ }^{[5]}$. The HOX genes encode transcription factors that are characterized at the protein level by a highly conserved DNA-binding domain, known as the homeodomain, and their expression defines the identity of cells primarily along the anterior to posterior axis of the embryo, both in the main body and within organs and appendages ${ }^{[6]}$. Mammals have 39 HOX genes that are organized in 4 distinct chromosomal clusters named A, B, C, and D. The HOX genes are named on the basis of which cluster they are found in, and their position within the cluster. Thus for example HOXB1 is the 3' most member of the HOXB cluster, and its immediate $5^{\prime}$ neighbor is consequently named HOXB2 $2^{[7]}$. The clusters arose through multiple duplication events during the evolution of vertebrates, and consequently $\mathrm{HOX}$ genes at equivalent positions within each cluster (e.g. HOXA1, HOXB1, HOXC1, and $H O X D 1$ ) share high levels of sequence identity beyond the conserved homeodomain region, and are referred to as paralogues ${ }^{[5]}$. The sharing of enhancer regions within clusters confers unusual regulatory properties on HOX genes, whereby the 3' members are expressed earlier in development (temporal collinearity) and more anteriorly (spatial collinearity) than their $5^{\prime}$ neighbors ${ }^{[8]}$.

HOX proteins can bind as monomers to DNA, although the affinity and specificity of binding are considerably increased through an interaction with other homeodomain-containing transcription factors including Pre-B-cell Leukemia Homeobox (PBX) and Myeloid Ecotropic Viral Integration Site 1 Homolog (MEIS) proteins ${ }^{[9]}$. Of these, PBX can bind to HOX proteins from paralogue groups $1-11^{[10-12]}$, whilst MEIS binds to HOX9-13 proteins $^{[13]}$. Despite this increased binding specificity, HOX proteins exhibit high levels of functional redundancy in some contexts due to extensive sequence identity between paralogue group members and $3^{\prime}$ and 5 ' neighbors ${ }^{[14]}$.

HOX gene expression generally reduces before birth and many adult cells show either low levels of expression, or no expression. Exceptions include cells that maintain proliferative capacity in the adult, for example stem cells, and most notably hematopoietic stem cells (HSCs), which are dependent on the continued expression of HOXB4 for proliferation ${ }^{[15]}$. The subsequent differentiation of HSCs along different lineages and ultimately to mature blood cells is also dependent on distinct patterns of $H O X$ gene expression ${ }^{[16]}$. Other adult processes that are known to be at least partly dependent on HOX genes include the menstrual cycle ${ }^{[17]}$ and the differentiation of mesenchymal stem cells ${ }^{[18]}$. Over the last 20 years it has become increasing clear that HOX genes are also very highly dysregulated, and usually strongly over expressed in a wide range of haematological and solid malignancies compared to the cells form which these cancers originate ${ }^{[19,20]}$. The HOX genes have multiple functions in cancer, and can act both as tumor suppressors and oncogenes. Examples of the former include HOXA5, which can promote expression of the p53 tumor suppressor protein ${ }^{[21]}$, and HOXC12, which promotes cellular differentiation in follicular lymphoma ${ }^{[22]}$. However, the majority of reports indicate that $H O X$ genes have a pro-oncogenic role, including functions that support tumor growth and invasion such as angiogenesis, metastasis, and immune evasion ${ }^{[23]}$. At the cellular level, a generalized role for many HOX proteins in cancer appears to be to prevent apoptosis by inhibiting $c F O S^{[24-27]}$ and dual specificity protease 1 (DUSP1) expression ${ }^{[26,28,29]}$. DUSP1 is a tumour suppressor gene ${ }^{[30]}$, and whilst $c F o s$ is generally considered to be a protoncogene, cFos protein can also induce apoptosis through the activation of the cell death ligand, FAS1 ${ }^{[31-35]}$. Additional cellular functions of individual HOX proteins include DNA repair ${ }^{[36]}$ and the regulation of the cell cycle ${ }^{[37]}$. It has also become apparent that the HOX genes function to modify the tumour microenvironment, and it is this aspect of their biology that we focus on here.

\section{HOX GENES IN PROSTATE CANCER}

The role of HOX genes in prostate cancer has in general been more extensively studied than for other solid malignancies. HOXC4, HOXC5, HOXC6, and $H O X C 8$ have all been found to be highly expressed in lymph node metastases ${ }^{[38]}$, and HOXC6 and HOXC8 overexpression has also been demonstrated in primary tumors ${ }^{[25]}$. HOXC8 expression was also shown to be higher in tumors with a higher Gleason score ${ }^{[39]}$. Of these 4 HOX genes, HOXC6 is reported to be the most highly upregulated in primary, metastasized, and castrate-resistant prostate cancer, and the presence of HOXC6 RNA in urine might be a diagnostic marker for prostate cancer and a potential monitoring tool for disease progression ${ }^{[40]}$, and was shown to distinguish between high and low grade prostate tumors with a very high specificity when used in conjugation with a second urinary marker, $D L X 1^{[41]}$. In addition, disrupting the interaction between HOX proteins and their PBX cofactor using the competitive antagonist HXR9 ${ }^{[23]}$ causes apoptotic cell death in the prostate cancerderived cell lines LnCaP, DU145, and PC3, and was shown to block the growth of PC3 tumors in a mouse xenograft model[25]. 
The most extensively studied $H O X$ gene in prostate cancer is $H O X B 13$ due to its apparent role in androgen sensitivity. It has been shown to be highly expressed in androgen receptor (AR) positive prostate cancerderived cell lines, but only at a very low level in AR negative cell lines ${ }^{[42,43]}$, and to be strongly expressed in hormone-refractory tumors after initial treatment ${ }^{[44]}$. Furthermore, mutations in $\mathrm{HOXB13}$ are associated with an increased risk of prostate cancer. The G84E variant was found to significantly increase the risk of heredity prostate cancer ${ }^{[45]}$, and was present in around $5 \%$ of families with at least one affected member ${ }^{[46]}$. A second variant, G135E was found to be associated with an increased risk of prostate cancer in Chinese men ${ }^{[4]}$. At the cellular level the functional significance of these variants remains unclear; for example, HOXB13 G84E was not found to result in an appreciably different phenotype to the wild type gene when expressed in PNT2 cells ${ }^{[48]}$. However, a clear mechanistic basis for the pro-oncogenic role of HOXB13 has arisen over the last few years [Figure 1]. HOXB13 protein can function both as a repressor and activator of transcription. It represses the p21WAF1/ CIP1 ( $p 21$ ) tumor suppressor gene, which can block androgen-stimulated cell proliferation ${ }^{[49]}$, and has also been shown to bind directly to the enhancer region of the RFX6 gene, the product of which inhibits the proliferation, migration, and invasion of prostate cancer cells ${ }^{[50]}$. HOXB13 additionally represses prostate derived Ets factor (PDEF) expression, which in turn blocks the expression of matrix metalloproteinase 9 (MMP-9) and the anti-apoptotic protein survivin, and thus reduces the invasive potential of cells ${ }^{[51]}$. A further pro-oncogenic effect of HOXB13 is exerted through the upregulation of zinc transporters that in turn results in lower intracellular zinc concentrations. This reduces the level of inhibitor of NF-kB alpha $(I \kappa B \alpha)$ and promotes NF- $\kappa B \alpha$ signaling leading to increased invasion and metastasis ${ }^{[52]}$. Thus, HOXB13 exerts multiple tumor-promoting effects through the regulation of specific target genes.

In addition to their roles in regulating the proliferation and survival of prostate cancer cells, it has become apparent that the HOX genes are also instrumental in promoting changes to the tumor microenvironment that support metastasis and angiogenesis [Figure 2]. Each of these aspects will be considered in detail in

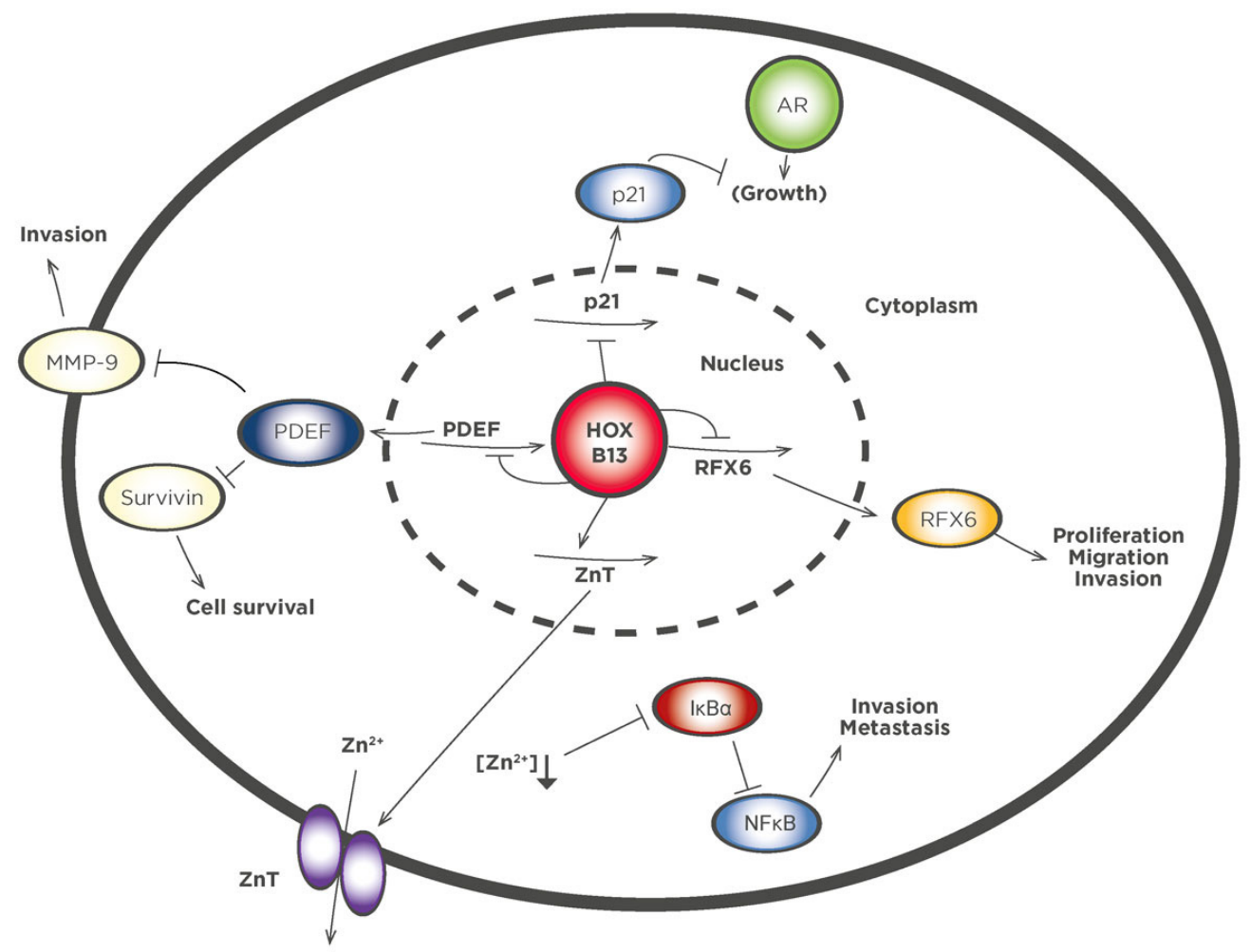

Figure 1: HOXB13 exerts multiple tumor-promoting effects through the regulation of specific target genes. HOXB13 protein can function both as a repressor and activator of transcription. It represses the p21WAF1/CIP1 (p21) tumor suppressor gene, which can block androgenstimulated cell proliferation and has also been shown to bind directly to the enhancer region of the RFX6 gene, the product of which inhibits the proliferation, migration, and invasion of prostate cancer cells. HOXB13 additionally represses prostate derived Ets factor (PDEF) expression, which in turn blocks the expression of matrix metalloproteinase 9 (MMP-9) and the anti-apoptotic protein survivin, and thus reduces the invasive potential of cells. A further pro-oncogenic effect of HOXB13 is exerted through the upregulation of zinc transporters

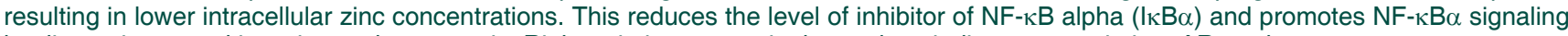
leading to increased invasion and metastasis. Right pointing arrows in the nucleus indicate transcription. AR: androgen receptor 
the remainder of this review.

\section{HOX TRANSCRIPTION FACTORS AND METASTASIS}

Metastasis is a complex, multi stage process and the tumor microenvironment plays a key role both at the earliest stages, in facilitating the movement of cells away from the primary tumor, and in the final stages in allowing metastatic cells to generate a new tumor at a distant site. One of the most important mechanisms by which tumors can modify the microenvironment is through the release of matrix metalloproteinases (MMPs), a family of zinc-dependent endopeptidases that can modify the extra cellular matrix $(E C M)^{[53]}$. Two of the most extensively studied of these enzymes with respect to prostate cancer are MMP-2 and MMP-9, both of which are members of the gelatinase subgroup of MMPs characterized by a fibronectin-like, gelatinbinding domain ${ }^{[54]}$. MMP-2 expression is higher in prostate tumors compared to normal prostate tissue, and has also been shown to be secreted by the former ${ }^{[55]}$, and reducing its expression in mouse melanoma B16F10 cells resulted in significantly fewer lung metastases $^{[56]}$. Both MMP-9 and MMP-2 expression is directly activated by the binding of HOXC11 protein to the enhancer region ${ }^{[57]}$, and HOXC11 is expressed in multiple prostate cancer cell types ${ }^{[25]}$ [Table 1]. MMP-9 expression has also been shown to be activated by HOXB7 in breast cancer cells ${ }^{[58]}$, and both MMP-9 and HOXB7 are over expressed in prostate cancer ${ }^{[25,53]}$. The most frequently used prostate cancer-derived cell lines are LNCaP, DU145 and PC3, of which PC3 has by far the higher capacity for invasion in vitro and shows a significantly higher level of MMP-9 expression compared to the other cell lines ${ }^{[59]}$. Correspondingly, the invasive capacity of LNCaP increased significantly when MMP-9 was experimentally over-expressed in these cells ${ }^{[6]}$, and invasion by DU145 and PC3 was reduced after MMP-9 expression was knocked-down using siRNA ${ }^{[61]}$.

In addition to the gelatinase class MMPs, the expression of two other MMPs, MMP-3 and MMP-14, is activated by HOX transcription factors ${ }^{[62,63]}$. MMP14 differs from other MMPs as it is membrane bound through a transmembrane domain with its catalytic center on the outside of the cell[64]. Its expression in prostate cancer cells is associated with androgen independence $^{[65]}$ and aggressiveness ${ }^{[6]}$. Prostate tumors primarily metastasize to bone, and MMP-14 has a particularly important role in this process due to

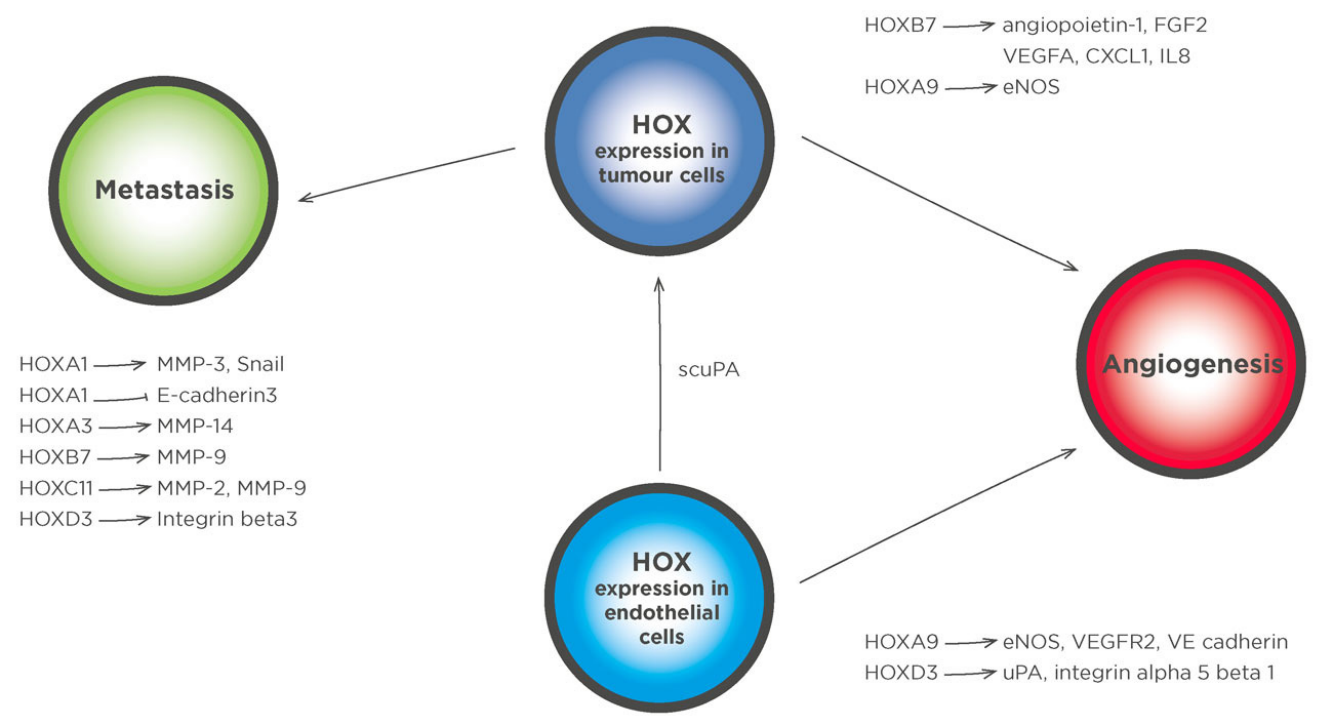

Figure 2: HOX transcription factors regulate genes in prostate cancer cells that modify the tumor microenvironment, as well genes in stromal cells that support tumor growth. HOX transcription factors have multiple roles in regulating genes that drive angiogenesis and metastasis. HOX targets with a key role in metastases include MMPs 2, 3, 9, and 14, as well as genes such as Snail and E-cadherin that are involved in the epithelial to mesenchymal transition. Genes involved in angiogenesis are also regulated by HOX transcription factors both in tumor cells and in endothelial cells. HOXD3 drives the expression of integrin alpha 5 beta 1 in endothelial cells which in turn leads to immature, leaky vessels. A number of HOX transcription factors can also drive the expression of proangiogenic secretory factors, including HOXB7, which regulates the transcription of FGF2, VEGFA, CXCL1, and IL8. An additional proangiogenic gene upregulated by HOXB7 is angiopoietin-1, the product of which plays a crucial role in stabilizing newly formed vasculature. Other proangiogenic genes that are regulated by HOX transcription factors include eNOs and uPA. HOXA9 expression in progenitor endothelial cells is necessary for their commitment to an endothelial lineage as it directly regulates endothelial specific genes such as eNOs, VE cadherin, and VEGFR2. HOXD3 has also been shown to have a role in vessel formation by endothelial cells through the activation of uPA transcription. In addition to an extracellular activity, a scuPA can be taken up by cancer cells in which it binds directly to HOXA5. MMP: matrix metalloproteinase; FGF2: fibroblast growth factor 2; VEGFA: vascular endothelial growth factor A; CXCL1: C-X-C motif ligand 1; IL8: interleukin 8; eNOs: endothelial nitric oxide synthase; UPA: urokinase plasminogen activator; scuPA: single chain form of UPA 
Table 1: Direct and indirect regulation of target genes by $H O X$ transcription factors in the context of the tumor microenvironment

\begin{tabular}{lccc}
\hline HOX protein & Target gene & $\begin{array}{c}\text { Direct or } \\
\text { indirect } \\
\text { regulation }\end{array}$ & Reference \\
\hline HOXA1 & MMP-3 & Unknown & {$[63]$} \\
HOXA1 & Snail & Unknown & {$[63]$} \\
HOXA1 & E-cadherin3 & Unknown & {$[63]$} \\
HOXA3 & MMP-14 & Unknown & {$[62]$} \\
HOXA9 & eNOS & Direct & {$[99]$} \\
HOXA9 & VEGFR2 & Direct & {$[99]$} \\
HOXA9 & VE cadherin & Direct & {$[99]$} \\
HOXB7 & MMP-9 & Unknown & {$[58]$} \\
HOXB7 & Angiopoietin-1 & Unknown & {$[58]$} \\
HOXB7 & FGF2 & Direct & {$[58,85]$} \\
HOXB7 & VEGFA & Unknown & {$[58]$} \\
HOXB7 & CXCL1 & Unknown & {$[58]$} \\
HOXB7 & IL8 & Unknown & {$[58]$} \\
HOXC11 & MMP-2 & Direct & {$[57]$} \\
HOXC11 & MMP-8 & Direct & {$[57]$} \\
HOXD3 & Integrin beta 3 & Indirect & {$[75]$} \\
HOXD3 & UPA & Unknown & {$[100]$} \\
HOXD3 & Integrin alpha 5 & Direct & {$[82]$} \\
& beta 1 & & \\
\hline
\end{tabular}

its ability to degrade collagen ${ }^{[67]}$. Accordingly, LNCaP cells overexpressing MMP-14 were shown to form significantly larger bone lesions in mice ${ }^{[67]}$. MMP-14 has been shown to be upregulated by HOXA3 expression ${ }^{[62]}$, and $H O X A 3$ is overexpressed in a number of cancers, including prostate cancer ${ }^{[25]}$. Another $\mathrm{HOX}$ gene linked to the progression of prostate cancer is HOXA1, the expression of which promotes the proliferation, invasion and metastasis of prostate cancer cells ${ }^{[63]}$. A number of key downstream target genes of HOXA1 have been identified, including MMP-3, which has itself been linked to prostate tumor progression in a number of studies ${ }^{[68-71]}$, and polymorphisms in the MMP-3 gene have been identified as a risk factor for the development of prostate cancer ${ }^{[72]}$.

In addition to the MMPs, HOX transcription factors regulate a number of other target genes involved in the interaction of prostate cancers cells with the ECM. These include HOXA1, which inhibits the expression of E-cadherin ${ }^{[63]}$, a major component of the epithelial adherence junctions that mediate intercellular interactions ${ }^{[73]}$. The downregulation of E-cadherin expression is one of the changes that occurs during the epithelial to mesenchymal transition, the activation of which in cancer cells is a key step in tumor invasion and metastasis ${ }^{[74]}$. The loss of E-cadherin also results in the disruption of the cytoplasmic cell adhesion complex, releasing proteins that can further modify the tumor microenvironment ${ }^{[73]}$. Another protein with a key function in cell adhesion is integrin $\beta 3$, elevated expression of which is positively associated with high levels of $H O X D 3$ expression ${ }^{[75]}$. Integrin $\beta 3$ has a role in tumor progression, invasion, and metastasis ${ }^{[76-78]}$, and is also associated with more aggressive behavior of prostate cancer bone metastases ${ }^{[79]}$. Correspondingly, integrin antagonists have been shown to reduce bone degradation in clinical trials ${ }^{[80]}$.

\section{HOX TRANSCRIPTION FACTORS AND ANGIOGENESIS}

Angiogenesis is a fundamental event in the natural history of tumors, allowing for their growth beyond a size restricted by the diffusion limits of nutrients and oxygen, and ultimately their systemic spread to form metastases ${ }^{[81]}$. HOX transcription factors have multiple roles in regulating the secretion of factors from tumor cells that drive this process in the microenvironment, and are also expressed in the cells of the tumor microvasculature in which they promote tumor-supportive functions. For the latter, HOXD3 has been shown to be particularly significant as it drives the expression of integrin alpha 5 beta 1 in endothelial cells which in turn leads to immature, leaky vessels that are typical of many tumor types ${ }^{[22]}$. Conversely, HOXA5, the expression of which results in more stable and less permeable vessels, is absent from tumor vessels ${ }^{[8,84]}$. Within tumor cells in has been shown that a number of HOX transcription factors can drive the expression of proangiogenic secretory factors. One of the earliest identified examples of this is $\mathrm{HOXB7}$, which drives fibroblast growth factor 2 (FGF2, also known as bFGF) expression in multiple cancer types ${ }^{[58,85]}$. FGF2 is a well characterized proangiogenic factor, and has been shown to induce tubule formation by endothelial cells when secreted from a prostate tumor in a rat model of this disease ${ }^{[8]}$. In addition to FGF2, HOXB7 drives the expression of vascular endothelial growth factor A (VEGFA), C-X-C motif ligand 1 (CXCL1), and interleukin $8(\text { IL8) })^{[58]}$. A role for IL8 in angiogenesis and its potential as a therapeutic target in cancer was demonstrated using fully-humanized antibodies to this protein in a mouse model of melanoma ${ }^{[87]}$, and it was subsequently shown that IL8 increases expression of the key proangiogenic ligand VEGF in endothelial cells resulting in a self-reinforcing, autocrine loop through the VEGF receptor 2 (VEGFR2) expressed on the surface of these cells ${ }^{[88]}$. Correspondingly, polymorphisms in the IL8 gene were shown to be associated with more aggressive prostate cancer ${ }^{[89]}$. CXCL1 is also a proangiogenic cytokine and has a potential role in the development of tumor resistance to anti-VEGF based therapy ${ }^{[00]}$, and in gastric cancer has been shown to promote tumor growth through the VEGF pathway ${ }^{[91]}$. Correspondingly, the down regulation of CXCL1 has been shown to mediate the enhancement of the antiangiogenic effects of docetaxel by dexamethasone in in vitro and in vivo models of prostate cancer ${ }^{[92]}$. 
Its proangiogenic effects are also mediated through non-VEGF pathways, including the downregulation of fibulin-1 in castrate resistant prostate cancer ${ }^{[03]}$. It is targeted by the tumor-suppressor microRNA (miR)200 that blocks angiogenesis and inhibits metastasis in multiple tumor types ${ }^{[94]}$.

An additional proangiogenic gene upregulated by HOXB7 is angiopoietin-1 (Ang-1) $)^{[58]}$, the product of which plays a crucial role in stabilizing newly formed vasculature. The binding of Ang-1 protein to its receptor on endothelial cells promotes their adherence to mural cells such as pericytes and smooth muscle cells ${ }^{[95-97]}$. Correspondingly, Ang1 secretion by prostate cancer cells in a xenograft model was shown to enhance tumor growth through an increased level of branching in the neovasculature ${ }^{[98]}$.

Additional proangiogenic genes that are regulated by HOX transcription factors include endothelial nitric oxide synthase (eNOs) ${ }^{[99]}$ and urokinase plasminogen activator (UPA) ${ }^{[100]}$. HOXA9 expression in progenitor endothelial cells within the tumor microenvironment was shown to be necessary for their commitment to an endothelial lineage, and it was also shown to directly regulate endothelial specific genes such as eNOs, VE cadherin, and VEGFR2 $2^{[99]}$. In this context HOXA9 was identified as a key target of histone deacetylases (HDACs), as its expression was significantly reduced after HDAC inhibitor treatment and this in turn blocked angiogenesis both in mice ${ }^{[99]}$ and in a clinical trial of combined HDAC and VEGF inhibitors for multiple cancers including advanced prostate cancer ${ }^{[101]}$. HOXD3 has also been shown to have a role in vessel formation by endothelial cells through the activation of $U P A$ transcription ${ }^{[100]}$. UPA is involved at all stages of angiogenesis, including endothelial cell division, migration, the formation of stable vessels, and the regulation of vascular permeability through proteolytic degradation of the extracellular matrix ${ }^{[102-104]}$. This is mediated through intracellular signaling initiated by its binding to receptors including uPA receptor (UPAR; CD87), low-density lipoprotein receptorrelated protein receptor (LRP/ $2 \mathrm{MR})$, and specific integrins $^{[105-110]}$. In addition, uPA converts plasminogen into serine protease plasmin ${ }^{[111,112]}$, which in turn breaks down matrix proteins and activates a number of MMPs ${ }^{[113-116]}$. UPAR-bound UPA has been shown in a number of studies to be localized to the leading edge of migrating cells ${ }^{[117-119]}$ to help ensure a focused degradation of the ECM and liberate matrix-bound proangiogenic factors, including VEGF ${ }^{[120-122]}$ and $\mathrm{FGF}^{[123,124]}$. In addition to an extracellular activity, a single chain form of uPA can be taken up by cancer cells and be translocated to the nucleus ${ }^{[125]}$ where it binds directly to HOXA5 protein and prevents it from activating the transcription of the key tumor suppressor gene $p 53^{[21]}$. Taken together, these studies imply the existence of a HOX-mediated feedback mechanism from the developing neovasculature to the tumor whereby HOXD3 promotes uPA expression in the endothelial cells, and this in turn blocks $p 53$ expression in the tumor, promoting cell proliferation and survival.

\section{CONCLUSION}

The evidence from previous studies indicates that the expression of HOX genes in the prostate tumor modifies the microenvironment in a manner that supports metastasis through degradation of the ECM, and angiogenesis through the secretion of proangiogenic cytokines. This is complemented by the expression of HOX genes in the microenvironment, particularly in endothelial cells, that promotes tumorsupportive functions including angiogenesis and the secretion of proteins that directly influence the malignant phenotype. Thus, targeting the function of HOX proteins may not only have a direct effect on tumor cells, but could also help reverse changes in the tumor microenvironment that would otherwise promote cancer progression.

\section{DECLARATIONS}

\section{Authors' contributions}

Performed the literature search and drafted the manuscript: R. Morgan

Helped write the manuscript and provided further interpretation of the referenced studies: H.S. Pandha

\section{Financial support and sponsorship}

None.

\section{Conflicts of interest}

The authors are shareholders in HOX Therapeutics Ltd., a company which is developing novel HOX/PBX binding antagonists, although these reagents are not discussed in this review.

\section{Patient consent}

Not applicable.

\section{Ethics approval}

Not applicable.

\section{REFERENCES}

1. Dai J, Lu Y, Roca H, Keller JM, Zhang J, McCauley LK, Keller ET. Immune mediators in the tumor microenvironment of prostate cancer. Chin J Cancer 2017;36:29. 
2. Huang Y, Yuan J, Righi E, Kamoun WS, Ancukiewicz M, Nezivar J, Santosuosso M, Martin JD, Martin MR, Vianello F, Leblanc P, Munn LL, Huang P, Duda DG, Fukumura D, Jain RK, Poznansky MC. Vascular normalizing doses of antiangiogenic treatment reprogram the immunosuppressive tumor microenvironment and enhance immunotherapy. Proc Natl Acad Sci U S A 2012;109:17561-6.

3. Niu YN, Xia SJ. Stroma-epithelium crosstalk in prostate cancer. Asian J Androl 2009;11:28-35.

4. Yoneda T, Hiraga T. Crosstalk between cancer cells and bone microenvironment in bone metastasis. Biochem Biophys Res Commun 2005;328:679-87.

5. Mallo M, Wellik DM, Deschamps J. Hox genes and regional patterning of the vertebrate body plan. Dev Biol 2010;344:7-15.

6. Gehring WJ. Homeo boxes in the study of development. Science 1987;236:1245-52.

7. Holland PW, Booth HA, Bruford EA. Classification and nomenclature of all human homeobox genes. BMC Biol 2007;5:47.

8. Platais C, Hakami F, Darda L, Lambert DW, Morgan R, Hunter KD. The role of HOX genes in head and neck squamous cell carcinoma. $J$ Oral Pathol Med 2016;45:239-47.

9. Longobardi E, Penkov D, Mateos D, De Florian G, Torres M, Blasi F. Biochemistry of the tale transcription factors PREP, MEIS, and PBX in vertebrates. Dev Dyn 2014;243:59-75.

10. Allen TD, Zhu YX, Hawley TS, Hawley RG. TALE homeoproteins as HOX11-interacting partners in T-cell leukemia. Leuk Lymphoma 2000;39:241-56.

11. Brendolan A, Ferretti E, Salsi V, Moses K, Quaggin S, Blasi F, Cleary ML, Selleri L. A Pbx1-dependent genetic and transcriptional network regulates spleen ontogeny. Development 2005;132:3113-26.

12. Piper DE, Batchelor AH, Chang CP, Cleary ML, Wolberger C. Structure of a HoxB1-Pbx1 heterodimer bound to DNA: role of the hexapeptide and a fourth homeodomain helix in complex formation. Cell 1999;96:587-97.

13. Williams TM, Williams ME, Innis JW. Range of HOX/TALE superclass associations and protein domain requirements for HOXA13:MEIS interaction. Dev Biol 2005;277:457-71.

14. Di-Poi N, Koch U, Radtke F, Duboule D. Additive and global functions of HoxA cluster genes in mesoderm derivatives. Dev Biol 2010;341:488-98.

15. Kyba M, Perlingeiro RC, Daley GQ. HoxB4 confers definitive lymphoid-myeloid engraftment potential on embryonic stem cell and yolk sac hematopoietic progenitors. Cell 2002;109:29-37.

16. Lebert-Ghali CE, Fournier M, Dickson GJ, Thompson A, Sauvageau G, Bijl JJ. HoxA cluster is haploinsufficient for activity of hematopoietic stem and progenitor cells. Exp Hematol 2010;38:1074-86.e1-5.

17. Xu B, Geerts D, Bu Z, Ai J, Jin L, Li Y, Zhang H, Zhu G. Regulation of endometrial receptivity by the highly expressed HOXA9, HOXA11 and HOXD10 HOX-class homeobox genes. Hum Reprod 2014;29:781-90.

18. Rux DR, Song JY, Swinehart IT, Pineault KM, Schlientz AJ, Trulik KG, Goldstein SA, Kozloff KM, Lucas D, Wellik DM. Regionally restricted Hox function in adult bone marrow multipotent mesenchymal stem/stromal cells. Dev Cell 2016;39:653-66.

19. Alharbi RA, Pettengell R, Pandha HS, Morgan R. The role of HOX genes in normal hematopoiesis and acute leukemia. Leukemia 2013;27:1000-8.

20. Shah N, Sukumar S. The Hox genes and their roles in oncogenesis. Nat Rev Cancer 2010;10:361-71.

21. Asuthkar S, Stepanova V, Lebedeva T, Holterman AL, Estes N, Cines DB, Rao JS, Gondi CS. Multifunctional roles of urokinase plasminogen activator (uPA) in cancer stemness and chemoresistance of pancreatic cancer. Mol Biol Cell 2013;24:2620-32.

22. Shang L, Pruett ND, Awgulewitsch A. Hoxc12 expression pattern in developing and cycling murine hair follicles. Mech Dev 2002;113:207-10.

23. Morgan R, El-Tanani M, Hunter KD, Harrington KJ, Pandha HS. Targeting HOX/PBX dimers in cancer. Oncotarget 2017;8:32322-31.

24. Morgan R, Boxall A, Harrington KJ, Simpson GR, Gillett C, Michael A, Pandha HS. Targeting the HOX/PBX dimer in breast cancer. Breast Cancer Res Treat 2012;136:389-98.

25. Morgan R, Boxall A, Harrington KJ, Simpson GR, Michael A, Pandha HS. Targeting HOX transcription factors in prostate cancer. BMC Urol 2014;14:17.

26. Morgan R, Pirard PM, Shears L, Sohal J, Pettengell R, Pandha HS. Antagonism of HOX/PBX dimer formation blocks the in vivo proliferation of melanoma. Cancer Res 2007;67:5806-13.

27. Morgan R, Simpson G, Gray S, Gillett C, Tabi Z, Spicer J, Harrington KJ, Pandha HS. HOX transcription factors are potential targets and markers in malignant mesothelioma. BMC Cancer 2015;16:85.

28. Morgan R, Plowright L, Harrington KJ, Michael A, Pandha HS. Targeting HOX and PBX transcription factors in ovarian cancer. BMC Cancer 2010;10:89.

29. Plowright L, Harrington KJ, Pandha HS, Morgan R. HOX transcription factors are potential therapeutic targets in non-small-cell lung cancer (targeting HOX genes in lung cancer). Br J Cancer 2009;100:470-5.

30. Ducruet AP, Vogt A, Wipf P, Lazo JS. Dual specificity protein phosphatases: therapeutic targets for cancer and Alzheimer's disease. Annu Rev Pharmacol Toxicol 2005;45:725-50.

31. Eichhorst ST, Muller M, Li-Weber M, Schulze-Bergkamen H, Angel P, Krammer PH. A novel AP-1 element in the CD95 ligand promoter is required for induction of apoptosis in hepatocellular carcinoma cells upon treatment with anticancer drugs. Mol Cell Biol 2000;20:7826-37.

32. Grimm C, Wenzel A, Behrens A, Hafezi F, Wagner EF, Remé CE. AP-1 mediated retinal photoreceptor apoptosis is independent of $\mathrm{N}$-terminal phosphorylation of c-Jun. Cell Death Differ 2001;8:859-67.

33. Hafezi F, Grimm C, Wenzel A, Abegg M, Yaniv M, Reme CE. Retinal photoreceptors are apoptosis-competent in the absence of JunD/AP-1. Cell Death Differ 1999;6:934-6.

34. Kasibhatla S, Brunner T, Genestier L, Echeverri F, Mahboubi A, Green DR. DNA damaging agents induce expression of Fas ligand and subsequent apoptosis in T lymphocytes via the activation of NFkappa B and AP-1. Mol Cell 1998;1:543-51.

35. Kolbus A, Herr I, Schreiber M, Debatin KM, Wagner EF, Angel P. c-Jun-dependent CD95-L expression is a rate-limiting step in the induction of apoptosis by alkylating agents. Mol Cell Biol 2000;20:575-82.

36. Rubin E, Wu X, Zhu T, Cheung JC, Chen H, Lorincz A, Pandita RK, Sharma GG, Ha HC, Gasson J, Hanakahi LA, Pandita TK, Sukumar $\mathrm{S}$. A role for the $\mathrm{HOXB7}$ homeodomain protein in DNA repair. Cancer Res 2007;67:1527-35.

37. Gabellini D, Colaluca IN, Vodermaier HC, Biamonti G, Giacca M, Falaschi A, Riva S, Peverali FA. Early mitotic degradation of the homeoprotein $\mathrm{HOXC10}$ is potentially linked to cell cycle progression. EMBO J 2003;22:3715-24.

38. Miller GJ, Miller HL, van Bokhoven A, Lambert JR, Werahera PN, Schirripa O, Lucia MS, Nordeen SK. Aberrant HOXC expression accompanies the malignant phenotype in human prostate. Cancer Res 2003;63:5879-88.

39. Waltregny D, Alami Y, Clausse N, de Leval J, Castronovo V. Overexpression of the homeobox gene HOXC8 in human prostate cancer correlates with loss of tumor differentiation. Prostate 2002;50:162-9.

40. Hamid AR, Hoogland AM, Smit F, Jannink S, van Rijt-van de Westerlo C, Jansen CF, van Leenders GJ, Verhaegh GW, Schalken JA. The role of HOXC6 in prostate cancer development. Prostate 2015;75:1868-76. 
41. Van Neste L, Hendriks RJ, Dijkstra S, Trooskens G, Cornel EB, Jannink SA, de Jong H, Hessels D, Smit FP, Melchers WJ, Leyten GH, de Reijke TM, Vergunst H, Kil P, Knipscheer BC, Hulsbergenvan de Kaa CA, Mulders PF, van Oort IM, Van Criekinge W, Schalken JA. Detection of high-grade prostate cancer using a urinary molecular biomarker-based risk score. Eur Urol 2016;70:740-8.

42. Jung C, Kim RS, Lee SJ, Wang C, Jeng MH. HOXB13 homeodomain protein suppresses the growth of prostate cancer cells by the negative regulation of T-cell factor 4. Cancer Res 2004;64:3046-51.

43. Jung C, Kim RS, Zhang HJ, Lee SJ, Jeng MH. HOXB13 induces growth suppression of prostate cancer cells as a repressor of hormoneactivated androgen receptor signaling. Cancer Res 2004;64:9185-92.

44. Kim YR, Oh KJ, Park RY, Xuan NT, Kang TW, Kwon DD, Choi C, Kim MS, Nam KI, Ahn KY, Jung C. HOXB13 promotes androgen independent growth of $\mathrm{LNCaP}$ prostate cancer cells by the activation of E2F signaling. Mol Cancer 2010;9:124.

45. Ewing CM, Ray AM, Lange EM, Zuhlke KA, Robbins CM, Tembe WD, Wiley KE, Isaacs SD, Johng D, Wang Y, Bizon C, Yan G, Gielzak M, Partin AW, Shanmugam V, Izatt T, Sinari S, Craig DW, Zheng SL, Walsh PC, Montie JE, Xu J, Carpten JD, Isaacs WB, Cooney KA. Germline mutations in HOXB13 and prostate-cancer risk. N Engl J Med 2012;366:141-9.

46. Xu J, Lange EM, Lu L, Zheng SL, Wang Z, Thibodeau SN, CannonAlbright LA, Teerlink CC, Camp NJ, Johnson AM, Zuhlke KA, Stanford JL, Ostrander EA, Wiley KE, Isaacs SD, Walsh PC, Maier C, Luedeke M, Vogel W, Schleutker J, Wahlfors T, Tammela T, Schaid D, McDonnell SK, DeRycke MS, Cancel-Tassin G, Cussenot O, Wiklund F, Grönberg H, Eeles R, Easton D, Kote-Jarai Z, Whittemore AS, Hsieh CL, Giles GG, Hopper JL, Severi G, Catalona WJ, Mandal D, Ledet E, Foulkes WD, Hamel N, Mahle L, Moller P, Powell I, Bailey-Wilson JE, Carpten JD, Seminara D, Cooney KA, Isaacs WB; International Consortium for Prostate Cancer Genetics. HOXB13 is a susceptibility gene for prostate cancer: results from the International Consortium for Prostate Cancer Genetics (ICPCG). Hum Genet 2013;132:5-14.

47. Lin X, Qu L, Chen Z, Xu C, Ye D, Shao Q, Wang X, Qi J, Chen Z, Zhou F, Wang M, Wang Z, He D, Wu D, Gao X, Yuan J, Wang G, Xu Y, Wang G, Dong P, Jiao Y, Yang J, Ou-Yang J, Jiang H, Zhu Y, Ren S, Zhang Z, Yin C, Wu Q, Zheng Y, Turner AR, Tao S, Na R, Ding Q, Lu D, Shi R, Sun J, Liu F, Zheng SL, Mo Z, Sun Y, Xu J. A novel germline mutation in HOXB13 is associated with prostate cancer risk in Chinese men. Prostate 2013;73:169-75.

48. Cardoso M, Maia S, Paulo P, Teixeira MR. Oncogenic mechanisms of HOXB13 missense mutations in prostate carcinogenesis. Oncoscience 2016;3:288-96.

49. Kim YR, Kang TW, To PK, Xuan Nguyen NT, Cho YS, Jung C, Kim MS. HOXB13-mediated suppression of p21WAF1/CIP1 regulates JNK/c-Jun signaling in prostate cancer cells. Oncol Rep 2016;35:2011-6.

50. Huang Q, Whitington T, Gao P, Lindberg JF, Yang Y, Sun J, Vaisanen MR, Szulkin R, Annala M, Yan J, Egevad LA, Zhang K, Lin R, Jolma A, Nykter M, Manninen A, Wiklund F, Vaarala MH, Visakorpi T, Xu J, Taipale J, Wei GH. A prostate cancer susceptibility allele at 6q22 increases RFX6 expression by modulating HOXB13 chromatin binding. Nat Genet 2014;46:126-35.

51. Kim IJ, Kang TW, Jeong T, Kim YR, Jung C. HOXB13 regulates the prostate-derived Ets factor: implications for prostate cancer cell invasion. Int J Oncol 2014;45:869-76.

52. Kim YR, Kim IJ, Kang TW, Choi C, Kim KK, Kim MS, Nam KI, Jung C. HOXB13 downregulates intracellular zinc and increases NFkappaB signaling to promote prostate cancer metastasis. Oncogene 2014;33:4558-67.

53. Gong Y, Chippada-Venkata UD, Oh WK. Roles of matrix metalloproteinases and their natural inhibitors in prostate cancer progression. Cancers (Basel) 2014;6:1298-327.

54. Chambers AF, Matrisian LM. Changing views of the role of matrix metalloproteinases in metastasis. J Natl Cancer Inst 1997;89:1260-70.

55. Lokeshwar BL, Selzer MG, Block NL, Gunja-Smith Z. Secretion of matrix metalloproteinases and their inhibitors (tissue inhibitor of metalloproteinases) by human prostate in explant cultures: reduced tissue inhibitor of metalloproteinase secretion by malignant tissues. Cancer Res 1993;53:4493-8.

56. Itoh T, Tanioka M, Yoshida H, Yoshioka T, Nishimoto H, Itohara S. Reduced angiogenesis and tumor progression in gelatinase A-deficient mice. Cancer Res 1998;58:1048-51.

57. Pruett ND, Hajdu Z, Zhang J, Visconti RP, Kern MJ, Wellik DM, Majesky MW, Awgulewitsch A. Changing topographic Hox expression in blood vessels results in regionally distinct vessel wall remodeling. Biol Open 2012;1:430-5.

58. Care A, Felicetti F, Meccia E, Bottero L, Parenza M, Stoppacciaro A, Peschle C, Colombo MP. HOXB7: a key factor for tumor-associated angiogenic switch. Cancer Res 2001;61:6532-9.

59. Aalinkeel R, Nair MP, Sufrin G, Mahajan SD, Chadha KC, Chawda RP, Schwartz SA. Gene expression of angiogenic factors correlates with metastatic potential of prostate cancer cells. Cancer Res 2004;64:5311-21.

60. Aalinkeel R, Nair BB, Reynolds JL, Sykes DE, Mahajan SD, Chadha KC, Schwartz SA. Overexpression of MMP-9 contributes to invasiveness of prostate cancer cell line LNCaP. Immunol Invest 2011;40:447-64.

61. Nalla AK, Gorantla B, Gondi CS, Lakka SS, Rao JS. Targeting MMP9, uPAR, and cathepsin B inhibits invasion, migration and activates apoptosis in prostate cancer cells. Cancer Gene Ther 2010;17:599-613.

62. Mace KA, Hansen SL, Myers C, Young DM, Boudreau N. HOXA3 induces cell migration in endothelial and epithelial cells promoting angiogenesis and wound repair. J Cell Sci 2005;118:2567-77.

63. Wang H, Liu G, Shen D, Ye H, Huang J, Jiao L, Sun Y. HOXA1 enhances the cell proliferation, invasion and metastasis of prostate cancer cells. Oncol Rep 2015;34:1203-10.

64. Li XY, Ota I, Yana I, Sabeh F, Weiss SJ. Molecular dissection of the structural machinery underlying the tissue-invasive activity of membrane type-1 matrix metalloproteinase. Mol Biol Cell 2008;19:3221-33.

65. Jennbacken K, Gustavsson H, Welen K, Vallbo C, Damber JE. Prostate cancer progression into androgen independency is associated with alterations in cell adhesion and invasivity. Prostate 2006;66:1631-40.

66. Wang X, Wilson MJ, Slaton JW, Sinha AA, Ewing SL, Pei D. Increased aggressiveness of human prostate PC-3 tumor cells expressing cell surface localized membrane type-1 matrix metalloproteinase (MT1MMP). J Androl 2009;30:259-74.

67. Bonfil RD, Dong Z, Trindade Filho JC, Sabbota A, Osenkowski P, Nabha S, Yamamoto H, Chinni SR, Zhao H, Mobashery S, Vessella RL, Fridman R, Cher ML. Prostate cancer-associated membrane type 1-matrix metalloproteinase: a pivotal role in bone response and intraosseous tumor growth. Am J Pathol 2007;170:2100-11.

68. Chen J, Wang Z, Xu D, Liu Y, Gao Y. Aquaporin 3 promotes prostate cancer cell motility and invasion via extracellular signal-regulated kinase 1/2-mediated matrix metalloproteinase-3 secretion. Mol Med Rep 2015;11:2882-8.

69. Slavin S, Yeh CR, Da J, Yu S, Miyamoto H, Messing EM, Guancial E, Yeh S. Estrogen receptor alpha in cancer-associated fibroblasts suppresses prostate cancer invasion via modulation of thrombospondin 2 and matrix metalloproteinase 3. Carcinogenesis 2014;35:1301-9.

70. Zhang L, Zhao L, Zhao D, Lin G, Guo B, Li Y, Liang Z, Zhao XJ, Fang $X$. Inhibition of tumor growth and induction of apoptosis in prostate cancer cell lines by overexpression of tissue inhibitor of matrix metalloproteinase-3. Cancer Gene Ther 2010;17:171-9. 
71. Zhu F, Liu P, Li J, Zhang Y. Eotaxin-1 promotes prostate cancer cell invasion via activation of the CCR3-ERK pathway and upregulation of MMP-3 expression. Oncol Rep 2014;31:2049-54.

72. Srivastava P, Kapoor R, Mittal RD. Impact of MMP-3 and TIMP-3 gene polymorphisms on prostate cancer susceptibility in North Indian cohort. Gene 2013;530:273-7.

73. Kalluri R, Weinberg RA. The basics of epithelial-mesenchymal transition. J Clin Invest 2009;119:1420-8.

74. Grant CM, Kyprianou N. Epithelial mesenchymal transition (EMT) in prostate growth and tumor progression. Transl Androl Urol 2013;2:202-11.

75. Shaoqiang C, Yue Z, Yang L, Hong Z, Lina Z, Da P, Qingyuan Z. Expression of HOXD3 correlates with shorter survival in patients with invasive breast cancer. Clin Exp Metastasis 2013;30:155-63.

76. Brooks PC, Montgomery AM, Rosenfeld M, Reisfeld RA, Hu T, Klier $\mathrm{G}$, Cheresh DA. Integrin alpha v beta 3 antagonists promote tumor regression by inducing apoptosis of angiogenic blood vessels. Cell 1994;79:1157-64.

77. Pidgeon GP, Tang K, Cai YL, Piasentin E, Honn KV. Overexpression of platelet-type 12-lipoxygenase promotes tumor cell survival by enhancing alpha(v)beta(3) and alpha(v)beta(5) integrin expression. Cancer Res 2003;63:4258-67.

78. Teitelbaum SL. Osteoclasts and integrins. Ann N Y Acad Sci 2006;1068:95-9.

79. Dresner-Pollak R, Rosenblatt M. Blockade of osteoclast-mediated bone resorption through occupancy of the integrin receptor: a potential approach to the therapy of osteoporosis. $J$ Cell Biochem 1994;56:323-30.

80. Rosenthal MA, Davidson P, Rolland F, Campone M, Xue L, Han TH, Mehta A, Berd Y, He W, Lombardi A. Evaluation of the safety, pharmacokinetics and treatment effects of an alpha(nu)beta(3) integrin inhibitor on bone turnover and disease activity in men with hormonerefractory prostate cancer and bone metastases. Asia Pac J Clin Oncol 2010;6:42-8.

81. Jayson GC, Kerbel R, Ellis LM, Harris AL. Antiangiogenic therapy in oncology: current status and future directions. Lancet 2016;388:518-29.

82. Boudreau NJ, Varner JA. The homeobox transcription factor Hox D3 promotes integrin alpha5betal expression and function during angiogenesis. J Biol Chem 2004;279:4862-8.

83. Arderiu G, Cuevas I, Chen A, Carrio M, East L, Boudreau NJ. HoxA5 stabilizes adherens junctions via increased Akt1. Cell Adh Migr 2007;1:185-95.

84. Rhoads K, Arderiu G, Charboneau A, Hansen SL, Hoffman W, Boudreau N. A role for Hox A5 in regulating angiogenesis and vascular patterning. Lymphat Res Biol 2005;3:240-52.

85. Care A, Silvani A, Meccia E, Mattia G, Stoppacciaro A, Parmiani G, Peschle C, Colombo MP. HOXB7 constitutively activates basic fibroblast growth factor in melanomas. Mol Cell Biol 1996;16:4842-51.

86. Matsuo M, Yamada S, Koizumi K, Sakurai H, Saiki I. Tumour-derived fibroblast growth factor-2 exerts lymphangiogenic effects through Akt/mTOR/p70S6kinase pathway in rat lymphatic endothelial cells. Eur J Cancer 2007;43:1748-54.

87. Huang S, Mills L, Mian B, Tellez C, McCarty M, Yang XD, Gudas JM, Bar-Eli M. Fully humanized neutralizing antibodies to interleukin-8 (ABX-IL8) inhibit angiogenesis, tumor growth, and metastasis of human melanoma. Am J Pathol 2002;161:125-34.

88. Martin D, Galisteo R, Gutkind JS. CXCL8/IL8 stimulates vascular endothelial growth factor (VEGF) expression and the autocrine activation of VEGFR2 in endothelial cells by activating NFkappaB through the CBM (Carma3/Bcl10/Malt1) complex. J Biol Chem 2009;284:6038-42.

89. Zabaleta J, Su LJ, Lin HY, Sierra RA, Hall MC, Sartor AO, Clark
PE, Hu JJ, Ochoa AC. Cytokine genetic polymorphisms and prostate cancer aggressiveness. Carcinogenesis 2009;30:1358-62.

90. Carbone C, Tamburrino A, Piro G, Boschi F, Cataldo I, Zanotto M, Mina MM, Zanini S, Sbarbati A, Scarpa A, Tortora G, Melisi D. Combined inhibition of IL1, CXCR1/2, and TGFbeta signaling pathways modulates in-vivo resistance to anti-VEGF treatment. Anticancer Drugs 2016;27:29-40.

91. Wei ZW, Xia GK, Wu Y, Chen W, Xiang Z, Schwarz RE, Brekken RA, Awasthi N, He YL, Zhang CH. CXCL1 promotes tumor growth through VEGF pathway activation and is associated with inferior survival in gastric cancer. Cancer Lett 2015;359:335-43.

92. Wilson C, Scullin P, Worthington J, Seaton A, Maxwell P, O'Rourke D, Johnston PG, McKeown SR, Wilson RH, O’Sullivan JM, Waugh DJ. Dexamethasone potentiates the antiangiogenic activity of docetaxel in castration-resistant prostate cancer. Br J Cancer 2008;99:2054-64.

93. Kuo PL, Shen KH, Hung SH, Hsu YL. CXCL1/GROalpha increases cell migration and invasion of prostate cancer by decreasing fibulin-1 expression through NF-kappaB/HDAC1 epigenetic regulation. Carcinogenesis 2012;33:2477-87.

94. Pecot CV, Rupaimoole R, Yang D, Akbani R, Ivan C, Lu C, Wu S, Han HD, Shah MY, Rodriguez-Aguayo C, Bottsford-Miller J, Liu Y, Kim SB, Unruh A, Gonzalez-Villasana V, Huang L, Zand B, MorenoSmith M, Mangala LS, Taylor M, Dalton HJ, Sehgal V, Wen Y, Kang Y, Baggerly KA, Lee JS, Ram PT, Ravoori MK, Kundra V, Zhang X, Ali-Fehmi R, Gonzalez-Angulo AM, Massion PP, Calin GA, LopezBerestein G, Zhang W, Sood AK. Tumour angiogenesis regulation by the miR-200 family. Nat Commun 2013;4:2427.

95. Dumont DJ, Gradwohl G, Fong GH, Puri MC, Gertsenstein M, Auerbach A, Breitman ML. Dominant-negative and targeted null mutations in the endothelial receptor tyrosine kinase, tek, reveal a critical role in vasculogenesis of the embryo. Genes Dev 1994;8:1897-909.

96. Sato TN, Tozawa Y, Deutsch U, Wolburg-Buchholz K, Fujiwara Y, Gendron-Maguire M, Gridley T, Wolburg H, Risau W, Qin Y. Distinct roles of the receptor tyrosine kinases Tie-1 and Tie-2 in blood vessel formation. Nature 1995;376:70-4.

97. Suri C, Jones PF, Patan S, Bartunkova S, Maisonpierre PC, Davis $\mathrm{S}$, Sato TN, Yancopoulos GD. Requisite role of angiopoietin-1, a ligand for the TIE2 receptor, during embryonic angiogenesis. Cell 1996;87:1171-80.

98. Satoh N, Yamada Y, Kinugasa Y, Takakura N. Angiopoietin-1 alters tumor growth by stabilizing blood vessels or by promoting angiogenesis. Cancer Sci 2008;99:2373-9.

99. Rossig L, Urbich C, Bruhl T, Dernbach E, Heeschen C, Chavakis E, Sasaki K, Aicher D, Diehl F, Seeger F, Potente M, Aicher A, Zanetta L, Dejana E, Zeiher AM, Dimmeler S. Histone deacetylase activity is essential for the expression of HoxA9 and for endothelial commitment of progenitor cells. J Exp Med 2005;201:1825-35.

100. Boudreau N, Andrews C, Srebrow A, Ravanpay A, Cheresh DA. Induction of the angiogenic phenotype by Hox D3. J Cell Biol 1997; 139:257-64.

101. Wheler JJ, Janku F, Falchook GS, Jackson TL, Fu S, Naing A, Tsimberidou AM, Moulder SL, Hong DS, Yang H, Piha-Paul SA, Atkins JT, Garcia-Manero G, Kurzrock R. Phase I study of anti-VEGF monoclonal antibody bevacizumab and histone deacetylase inhibitor valproic acid in patients with advanced cancers. Cancer Chemother Pharmacol 2014;73:495-501.

102. Devy L, Blacher S, Grignet-Debrus C, Bajou K, Masson V, Gerard RD, Gils A, Carmeliet G, Carmeliet P, Declerck PJ, Noel A, Foidart JM. The pro- or antiangiogenic effect of plasminogen activator inhibitor 1 is dose dependent. FASEB J 2002;16:147-54.

103. Montuori N, Ragno P. Role of uPA/uPAR in the modulation of angiogenesis. Chem Immunol Allergy 2014;99:105-22. 
104. Traktuev DO, Tsokolaeva ZI, Shevelev AA, Talitskiy KA, Stepanova VV, Johnstone BH, Rahmat-Zade TM, Kapustin AN, Tkachuk VA, March KL, Parfyonova YV. Urokinase gene transfer augments angiogenesis in ischemic skeletal and myocardial muscle. Mol Ther 2007; 15:1939-46.

105. Cubellis MV, Nolli ML, Cassani G, Blasi F. Binding of single-chain prourokinase to the urokinase receptor of human U937 cells. $J$ Biol Chem 1986;261:15819-22.

106. Kwak SH, Mitra S, Bdeir K, Strassheim D, Park JS, Kim JY, Idell S, Cines D, Abraham E. The kringle domain of urokinase-type plasminogen activator potentiates LPS-induced neutrophil activation through interaction with $\{$ alpha $\} \mathrm{V}$ \{beta 3 integrins. J Leukoc Biol 2005;78:937-45.

107. Mazar AP, Henkin J, Goldfarb RH. The urokinase plasminogen activator system in cancer: implications for tumor angiogenesis and metastasis. Angiogenesis 1999;3:15-32.

108. Nykjaer A, Kjoller L, Cohen RL, Lawrence DA, Garni-Wagner BA, Todd RF, 3rd, van Zonneveld AJ, Gliemann J, Andreasen PA. Regions involved in binding of urokinase-type-1 inhibitor complex and pro-urokinase to the endocytic alpha 2-macroglobulin receptor/ low density lipoprotein receptor-related protein. Evidence that the urokinase receptor protects pro-urokinase against binding to the endocytic receptor. J Biol Chem 1994;269:25668-76.

109. Pluskota E, Soloviev DA, Bdeir K, Cines DB, Plow EF. Integrin alphaMbeta2 orchestrates and accelerates plasminogen activation and fibrinolysis by neutrophils. J Biol Chem 2004;279:18063-72.

110. Tarui T, Akakura N, Majumdar M, Andronicos N, Takagi J, Mazar AP, Bdeir K, Kuo A, Yarovoi SV, Cines DB, Takada Y. Direct interaction of the kringle domain of urokinase-type plasminogen activator (uPA) and integrin alpha $\mathrm{v}$ beta 3 induces signal transduction and enhances plasminogen activation. Thromb Haemost 2006;95:524-34.

111. Miles LA, Greengard JS, Griffin JH. A comparison of the abilities of plasma kallikrein, beta-Factor XIIa, Factor XIa and urokinase to activate plasminogen. Thromb Res 1983;29:407-17.

112. Peltz SW, Hardt TA, Mangel WF. Positive regulation of activation of plasminogen by urokinase: differences in $\mathrm{Km}$ for (glutamic acid)plasminogen and lysine-plasminogen and effect of certain alpha, omega-amino acids. Biochemistry 1982;21:2798-804.

113. Baramova EN, Bajou K, Remacle A, L'Hoir C, Krell HW, Weidle $\mathrm{UH}$, Noel A, Foidart JM. Involvement of PA/plasmin system in the processing of pro-MMP-9 and in the second step of pro-MMP-2 activation. FEBS Lett 1997;405:157-62.

114. Makowski GS, Ramsby ML. Binding oflatent matrix metalloproteinase
9 to fibrin: activation via a plasmin-dependent pathway. Inflammation 1998;22:287-305.

115. Matrisian LM. The matrix-degrading metalloproteinases. Bioessays 1992;14:455-63.

116. Okumura Y, Sato H, Seiki M, Kido H. Proteolytic activation of the precursor of membrane type 1 matrix metalloproteinase by human plasmin. A possible cell surface activator. FEBS Lett 1997;402:181-4.

117. Alexander RA, Prager GW, Mihaly-Bison J, Uhrin P, Sunzenauer S Binder BR, Schutz GJ, Freissmuth M, Breuss JM. VEGF-induced endothelial cell migration requires urokinase receptor (UPAR)dependent integrin redistribution. Cardiovasc Res 2012;94:125-35.

118. Estreicher A, Muhlhauser J, Carpentier JL, Orci L, Vassalli JD. The receptor for urokinase type plasminogen activator polarizes expression of the protease to the leading edge of migrating monocytes and promotes degradation of enzyme inhibitor complexes. J Cell Biol 1990;111:783-92.

119. Prager GW, Breuss JM, Steurer S, Olcaydu D, Mihaly J, Brunner PM, Stockinger H, Binder BR. Vascular endothelial growth factor receptor-2-induced initial endothelial cell migration depends on the presence of the urokinase receptor. Circ Res 2004;94:1562-70.

120. Ferrara N. Binding to the extracellular matrix and proteolytic processing: two key mechanisms regulating vascular endothelial growth factor action. Mol Biol Cell 2010;21:687-90.

121. Matsuno H, Kozawa O, Yoshimi N, Akamatsu S, Hara A, Mori H, Okada K, Ueshima S, Matsuo O, Uematsu T. Lack of alpha2antiplasmin promotes pulmonary heart failure via overrelease of VEGF after acute myocardial infarction. Blood 2002;100:2487-93.

122. Park JE, Keller GA, Ferrara N. The vascular endothelial growth factor (VEGF) isoforms: differential deposition into the subepithelial extracellular matrix and bioactivity of extracellular matrix-bound VEGF. Mol Biol Cell 1993;4:1317-26.

123. Koolwijk P, van Erck MG, de Vree WJ, Vermeer MA, Weich HA, Hanemaaijer R, van Hinsbergh VW. Cooperative effect of TNFalpha, bFGF, and VEGF on the formation of tubular structures of human microvascular endothelial cells in a fibrin matrix. Role of urokinase activity. J Cell Biol 1996;132:1177-88.

124. Saksela O, Rifkin DB. Release of basic fibroblast growth factorheparan sulfate complexes from endothelial cells by plasminogen activator-mediated proteolytic activity. J Cell Biol 1990;110:767-75.

125. Stepanova V, Lebedeva T, Kuo A, Yarovoi S, Tkachuk S, Zaitsev S, Bdeir K, Dumler I, Marks MS, Parfyonova Y, Tkachuk VA, Higazi AA, Cines DB. Nuclear translocation of urokinase-type plasminogen activator. Blood 2008;112:100-10. 